J. Amer. Soc. Hort. Sci. 116(4):684-688. 1991,

\title{
Osmotic Adjustment and Solute Constituents in Leaves and Roots of Water-stressed Cherry (Prunus) Trees
}

\author{
Thomas G. Ranney ${ }^{1}$, Nina L. Bassuk, and Thomas H. Whitlow \\ Department of Floriculture and Ornamental Horticulture, Cornell University, Ithaca, NY 14853
}

Additional index words. Prunus avium $\times$ pseudocerasus 'Colt', Prunus cerasus 'Meteor', drought, osmoregulation, polyols, solute accumulation, sorbitol, water relations

Abstract. Tissue osmotic potential $\left(\boldsymbol{\Psi}_{\boldsymbol{\pi}}\right)$ and solute constituents were evaluated in leaves and roots of well-watered and water-stressed Prunus avium L. $\times$ pseudocerasus Lindl. 'Colt' and Prunus cerasus L. 'Meteor'. Osmotic potential at full turgor $\left(\boldsymbol{\Psi}_{\boldsymbol{\pi} \text {,sat }}\right)$ decreased in response to water stress for leaves and roots of both cultivars. For 'Colt', a cultivar with an indeterminate growth habit, $\boldsymbol{\Psi}_{\boldsymbol{\pi} \text {,sat }}$ decreased by $0.56 \mathrm{MPa}$ and $0.38 \mathrm{MPa}$ for terminal expanding leaves and older expanded leaves, respectively. For 'Meteor', a cultivar with a determinate growth habit $\boldsymbol{\Psi}_{\pi, \text { sat }}$ decreased by $\approx 0.47 \mathrm{MPa}$ in both terminal and older leaves. $\operatorname{Root} \boldsymbol{\Psi}_{\boldsymbol{\pi}, \mathbf{s a t}}$ was alike for both cultivars and showed a similar decrease of $0.20 \mathrm{MPa}$ in response to water stress. Roots had considerably highe $\boldsymbol{\Psi}_{\pi, \mathbf{s a t}}$ than did leaves in both cultivars, irrespective of irrigation treatment. Soluble carbohydrates and potassium $\left(\mathrm{K}^{+}\right)$were the major solute constituents in both cultivars. Of the soluble carbohydrates, sorbitol was found in the greatest concentration and accounted for the bulk of water stress-induced solute accumulation in both cultivars. Regardless of the irrigation treatment, mature leaves of 'Meteor' consistently had lower $\boldsymbol{\Psi}_{\pi, \text { sat }}$ (typically $0.4 \mathrm{MPa}$ ) than 'Colt'. This variation in $\boldsymbol{\Psi}_{\boldsymbol{\pi} \text {,sat }}$ between Prunus cultivars suggests the potential for selection of cultivars with low $\boldsymbol{\Psi}_{\mathbf{m}, \mathbf{s a t}}$ and possibly superior drought resistance.

The capacity for osmotic adjustment via solute accumulation has been reported for many woody plants (Hinckley et al., 1981; Jones et al., 1985; Tyree and Jarvis, 1982). Higher solute concentrations contribute to lower tissue $\Psi_{\pi}$, maintenance of turgor potential, and improved tolerance of low tissue water potentials (Tyree and Jarvis, 1982). Low $\Psi_{\pi}$ and the capacity for osmotic adjustment may also serve as useful criteria for selection and breeding of more drought-resistant species and cultivars (Tyree, 1976).

Tissue $\Psi_{\boldsymbol{\pi}}$ and the capacity for osmotic adjustment can vary among organs within a plant. In apple, mature leaves showed seasonal osmotic adjustment while shoot tips did not (Lakso, 1983; Lakso et al., 1984). Also, mature leaves of woody plants typically have lower $\Psi_{\pi}$ than do expanding leaves (Knipling, 1967; Lakso et al., 1984; Syvertsen et al., 1981; Tyree et al., 1978). This variation may be important in understanding the responses of leaf gas exchange and leaf area expansion to water stress (Jones et al., 1985). Osmotic adjustment also occurs in roots of woody plants in response to water stress (Kandiko et al., 1980; Osonubi and Davies, 1978; Parker and Pallardy, 1985, 1988). However, within a plant, roots typically have higher $\Psi_{\pi}$ than do leaves when compared at full turgor (Kandiko et al., 1980; Parker and Pallardy, 1985, 1988). The capacity for osmotic adjustment and turgor maintenance in roots may influence root : shoot partitioning patterns, root growth, and leaf responses to water deficits through indirect effects of root-produced plant growth regulators (Turner, 1986).

Soluble carbohydrates are often found to be important osmolytes, accumulating in response to water stress in herbaceous plants (Cutler and Rains, 1978; Ford and Wilson, 1981; Handa et al., 1983; Munns and Weir, 1981; Munns et al., 1979; Turner

Received for publication 1 Nov. 1990. The cost of publishing this paper was defrayed in part by the payment of page charges. Under postal regulations, this paper therefore must be hereby marked advertisement solely to indicate this fact.

'Present address: North Carolina State Univ., Dept. of Horticultural Science, Mountain Horticultural Crops Research and Extension Center, 2016 Fanning Bridge Road, Fletcher, NC 28732. Phone: (704) 684-3562. FAX: (704) 6848715 . et al., 1978). However, there has been little study of the solutes that contribute to $\Psi_{\pi}$ and osmotic adjustment in woody plants.

Alcohol sugars, or polyols, are important osmolytes in certain lichens, yeasts, algae, and fungi accumulating in response to osmotic stress (Bieleski, 1982). In one case, the polyol sorbitol accumulates in Plantago in response to salt stress (Ahmad et al., 1979). Sorbitol is the primary photosynthetic product and translocated carbohydrate in many woody rosaceous species (Bieleski, 1982), including Prunus, where substantial diurnal accumulation of sorbitol occurs (Rem et al., 1988). Jones et al., (1985) further hypothesized that sorbitol may be an important osmolyte contributing to osmotic adjustment in rosaceous fruit trees.

Our objectives were the comparison of variations in $\Psi_{\pi}$ and osmotic adjustment in response to water stress 1) between two Prunus cultivars, 2) between roots and leaves of different age, and 3) to determine the primary solutes that contribute to $\Psi_{\pi}$ and osmotic adjustment in these plants.

\section{Materials and Methods}

Plant material and handling. Prunus avium $\times$ pseudocerasus 'Colt' and P. cerasus 'Meteor', $0.6 \mathrm{~cm}$ in caliper, were potted in 19-liter white plastic containers with a medium of 1 sphagnum peat moss : 1 vermiculite : 1 calcined clay (by volume) on 20 May 1987. Before initiation of treatments, plants were grown outside under natural conditions in Ithaca, N.Y., and were fertilized weekly with water soluble fertilizer $\left(10 \mathrm{~N}-10 \mathrm{P}_{2} \mathrm{O}_{5}-10 \mathrm{~K}_{2} \mathrm{O}\right)$ at an $\mathrm{N}$ concentration of $200 \mathrm{mg} \cdot \mathrm{liter}^{-1}$. Plants were moved into the greenhouse where irrigation treatments commenced on 20 July 1987.

Treatments. The experiment was a split-unit design (Cochran and Cox, 1957) consisting of a $2 \times 2$ factorial with two cultivars (Meteor and Colt) and two irrigation levels (control and water-stressed) at the whole-unit level with leaves and roots within a plant treated as subunits. There were five replications per treatment combination. Plants were irrigated each evening

$\overline{\text { Abbreviations: }} \Psi_{\pi}$, osmotic potential; $\Psi_{\pi, \text { sat }}$, osmotic potential at full turgor. 
either to container through-flow (control) or with only sufficient water to restore a bulk soil water potential of - 1.2 MPa (waterstressed), based on a soil moisture release curve determined using a pressure chamber and ceramic plate (Soilmoisture Equipment Corp., Santa Barbara, Calif.). Imposition of water stress in this manner can result in variation in soil water content within a container at certain times. However, this method makes it possible to subject several plants to similar levels of water stress for extended periods. These irrigation treatments were imposed for 30 days.

Plant water relations. Leaf and root samples were collected before dawn to minimize variation in solute accumulation during the light period. Leaves were collected at four-node intervals along the current season's growth and at the shoot terminal. Because 'Colt' is a strongly indeterminate grower and did not set a terminal bud during the experiment, terminal leaves of 'Colt' were only partially expanded. In contrast, 'Meteor' plants had set terminal buds before sampling and terminal leaves were nearly mature (i.e., fully expanded). Roots were excised at a point where the root diameter was $5 \mathrm{~mm}$ and included the portion of the root system distal to the excision. Excised tissue was hydrated by recutting under water and holding for $2 \mathrm{~h}$, covered with plastic, in the dark, with the cut end submerged. This method was sufficient to fully rehydrate tissue, i.e., result in a water potential of $0 \mathrm{MPa} . \Psi_{\pi, \mathrm{yta}}$ determined on expressed sap from fully hydrated tissue after freezing and thawing. Osmolality of expressed sap was determined using a vapor pressure osmometer (Wescor model 5100C, Logan, Utah). The $\Psi_{\pi}$ of the expressed sap was then calculated for 20C, based on the van't Hoff relation as given by Nobel (1983):

$\Psi_{\pi}(\mathrm{MPa})=0.002437\left(\mathrm{~m}^{3} \cdot \mathrm{MPa} \cdot \mathrm{mol}^{-1}\right) *$ osmolality $\left(\mathrm{mol} \cdot \mathrm{m}^{-3}\right)$

The $\Psi_{\pi}$ of expressed sap represents a mixture of cell contents and can yield values of $\Psi_{\pi}$ slightly higher (more dilute) than would measurement of symplastic $\Psi_{\pi}$ due to the dilution of symplastic solutes by apoplastic water. However, previous research has shown that measurements of $\Psi_{\pi, \text { sat }}$ of expressed sap were well correlated with measurements of $\Psi_{\pi \text {,sat }}$ determined using pressure-volume methodology for leaves of apple (Lakso et al., 1984), over a range of $\Psi_{\pi \text {, sat }}$ from 0 to $-2.5 \mathrm{MPa}$, and for leaves of various ages and roots of both well-watered and water-stressed cherry trees (Ranney, 1989).

Solute analysis. Analysis for soluble carbohydrates and potassium was performed on terminal leaves, mature leaves (16th node), and roots after 30 days of irrigation treatments. Carbohydrates were extracted and then analyzed using high-performance liquid chromatography following Boersig and Negro (1985), modified by using a BioRad carbohydrate column (model HPX87C; BioRad, Richmond, Calif.) at 85C. Potassium was analyzed by inductively coupled argon plasma emission spectroscopy.

Osmotic contribution of solutes. The contribution of individual solutes to the osmotic potential of the expressed sap was calculated based on the relative dry weight (RDW) at saturation [dry weight/(saturated weight - dry weight)] determined for each sample, the solute concentration on a tissue dry-weight basis, the molecular weight of each solute, and the van't Hoff relation. Calculated at $20 \mathrm{C}$ this gives:

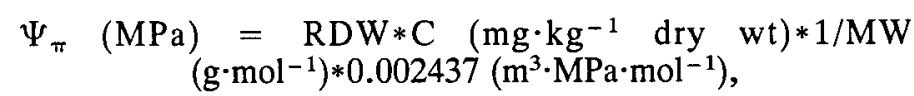

where $\mathrm{C}$ is the solute concentration and $\mathrm{MW}$ is the molecular weight of a given solute.

\section{Results}

Water stress induced decreases in $\Psi_{\pi \text {,sat }}$ for leaves and roots of both cultivars (Fig. 1). For 'Colt', terminal leaves had higher $\Psi_{\pi \text {,sat }}$ than older leaves when well-watered. When stressed, all leaves of 'Colt' adjusted osmotically, with the terminal leaves showing the greatest decrease in $\Psi_{\pi \text {,sat }}(0.56 \mathrm{MPa})$ while expanded leaves typically decreased by $0.38 \mathrm{MPa}$. This differential response resulted in all of the leaves having $\operatorname{similaH}_{\pi \text {,sat }}$ when stressed. The roots of 'Colt' had substantially higher $\Psi_{\pi \text {,sat }}$, than leaves, with a $\Psi_{\pi, \text { sat }}$ of -0.56 and $-0.74 \mathrm{MPa}$ for control and stressed plants, respectively.

There was no difference in $\Psi_{\pi \text {,sat }}$ among any of the leaves of well-irrigated 'Meteor' plants that had a mean lea $\Psi_{\pi \text {,sat }}$ of $-2.02 \mathrm{MPa}$ (Fig. 1). Leaves from node 12 (from the base) up to and including the terminal leaves showed similar decreases in $\Psi_{\pi \text {,sat }}$ of $0.47 \mathrm{MPa}$ in response to water stress. Leaves at node 8 decreased slightly $(0.17 \mathrm{MPa})$ and leaves at node 4 showed no significant osmotic adjustment. As with 'Colt', roots of 'Meteor' had higher $\Psi_{\pi \text {,sat }}$ than did leaves with ${ }^{2} \Psi_{\pi \text {,sat }}$ of $-0.57 \mathrm{MPa}$ and $-0.80 \mathrm{MPa}$ for control and stressed plants, respectively.

Comparison among cultivars showed that mature leaves of 'Meteor' consistently had lower $\Psi_{\text {m,sat }}$ (typically $0.4 \mathrm{MPa}$ ) than 'Colt' for plants under the same irrigation treatment except for node 4 where stress leaves of both 'Meteor' and 'Colt' had similar $\Psi_{\pi \text {,sat }}$. Roots showed very similar levels of $\Psi_{\pi \text {,sat }}$. Roots showed very similar levels of $\Psi_{\pi, \text { sat }}$ for both cultivars.

Analysis of tissue solutes showed that soluble carbohydrates and potassium were prominent solutes for 'Colt' and 'Meteor' (Table 1). Of the soluble carbohydrates, sorbitol was found in the greatest concentration regardless of cultivar, tissue, or irrigation treatment. Total soluble carbohydrates increased in response to the stress in leaves and roots of both cultivars. However, these increases in total soluble carbohydrates resulted primarily from increases in sorbitol alone. Concentrations of potassium, on a tissue dry-weight basis, did not change in response to the stress in leaves and actually decreased in roots of 'Colt' (Table 1). For 'Meteor', tissue dry-weight concentrations of potassium decreased in leaves and roots in response to stress.

The RDW at saturation increased significantly for terminal leaves and roots of both cultivars (Fig. 2). As a result, stressinduced changes in solute concentration, expressed as $\Psi_{\pi \text {,sat }}$

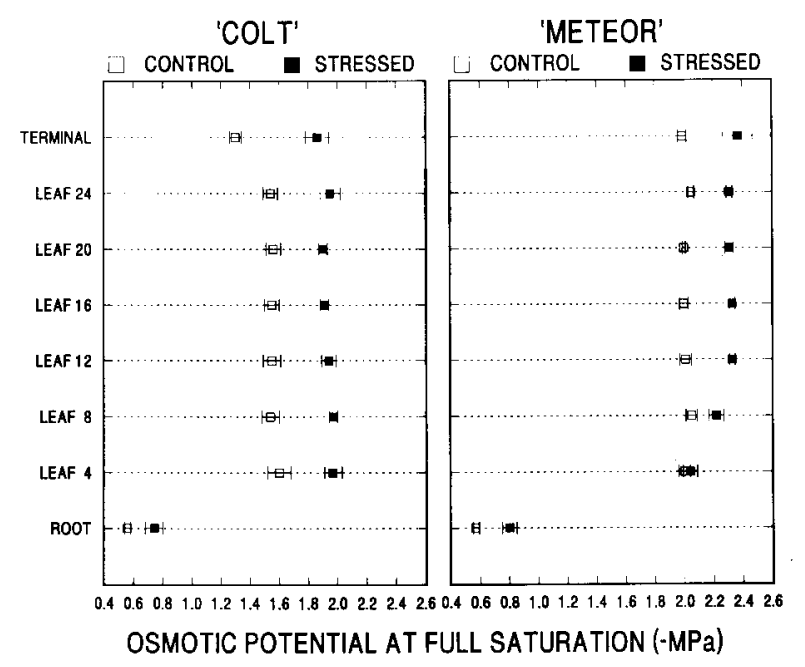

Fig. 1. $\Psi_{\pi, \text { sat }}$ for leaves and roots of control and water-stressed plants. Values are means \pm 1 SEM. 
varied considerably from changes in solute concentrations presented on a dry-weight basis (Table 1). It is therefore important to appreciate that comparison of solute concentrations on a dry-

Table 1. Influence of water stress on solute concentration and calculated $\Psi_{\pi \text {,sat }}$ for terminal leaves, mature leaves (16th node), and roots of 'Colt' and 'Meteor' cherry trees after 30 days of irrigation treatments.

\begin{tabular}{|c|c|c|c|c|c|}
\hline \multirow[b]{2}{*}{ Tissue } & \multirow[b]{2}{*}{ Solute } & \multicolumn{2}{|c|}{$\begin{array}{c}\text { Concn } \\
\left(\mathrm{mmol} \cdot \mathrm{kg}^{-1} \mathrm{dry} \mathrm{wt}\right) \\
\end{array}$} & \multicolumn{2}{|c|}{$\begin{array}{c}\text { Calculated } \\
\Psi_{\pi, \text { sat }}(-\mathrm{MPa} \\
\end{array}$} \\
\hline & & Control & Stressed & Control & Stresse \\
\hline & & Colt & & & \\
\hline \multirow[t]{8}{*}{$\begin{array}{c}\text { Terminal } \\
\text { leaves }\end{array}$} & Sugars & & & & \\
\hline & Glucose & 74.76 & 60.34 & 0.06 & 0.07 \\
\hline & Sucrose & 9.51 & 32.76 & 0.01 & $0.04^{*}$ \\
\hline & Sorbose & 0.00 & 3.94 & 0.00 & 0.00 \\
\hline & Fructose & 58.43 & 71.48 & 0.05 & $0.08^{* *}$ \\
\hline & Sorbitol & 193.0 & $488.3^{* *}$ & 0.16 & $0.53^{* *}$ \\
\hline & Total sugars & 335.7 & $656.8^{* *}$ & 0.28 & $0.72 * *$ \\
\hline & $\mathrm{K}^{+}$ & 443.0 & 428.8 & 0.37 & $0.46^{* *}$ \\
\hline \multirow{9}{*}{$\begin{array}{l}\text { Mature } \\
\text { leaves }\end{array}$} & & & & & \\
\hline & Sugars & & & & \\
\hline & Glucose & 70.90 & 88.10 & 0.06 & 0.08 \\
\hline & Sucrose & 56.82 & 27.15 & 0.05 & $0.02^{*}$ \\
\hline & Sorbose & 2.12 & 5.02 & 0.00 & 0.01 \\
\hline & Fructose & 59.21 & 70.74 & 0.05 & 0.06 \\
\hline & Sorbitol & 262.5 & $554.3^{* *}$ & 0.21 & $0.50^{* *}$ \\
\hline & Total sugars & 451.5 & $745.3^{* *}$ & 0.37 & $0.67^{* *}$ \\
\hline & $\mathrm{K}^{+}$ & 1021 & 919.9 & 0.84 & 0.82 \\
\hline \multirow[t]{8}{*}{ Roots } & Sugars & & & & \\
\hline & Glucose & 47.97 & 54.73 & 0.02 & 0.04 \\
\hline & Sucrose & 18.23 & 10.00 & 0.01 & 0.01 \\
\hline & Sorbose & 0.00 & 1.11 & 0.00 & 0.00 \\
\hline & Fructose & 34.37 & 44.43 & 0.02 & 0.03 \\
\hline & Sorbitol & 83.86 & $166.6^{*}$ & 0.04 & $0.12^{*}$ \\
\hline & Total sugars & 184.4 & $276.9^{*}$ & 0.08 & $0.20^{*}$ \\
\hline & $\mathrm{K}^{+}$ & 642.8 & $455.6^{* *}$ & 0.27 & 0.32 \\
\hline \multirow{9}{*}{$\begin{array}{c}\text { Terminal } \\
\text { leaves }\end{array}$} & & \multicolumn{2}{|l|}{ Meteor } & & \\
\hline & Sugars & & & & \\
\hline & Glucose & 65.48 & 60.35 & 0.07 & 0.07 \\
\hline & Sucrose & 41.52 & 20.40 & 0.04 & 0.02 \\
\hline & Sorbose & 0.00 & $14.05^{* *}$ & 0.00 & $0.02 *$ \\
\hline & Fructose & 61.63 & 56.09 & 0.06 & 0.06 \\
\hline & Sorbitol & 385.8 & $620.2^{* *}$ & 0.40 & $0.70^{* *}$ \\
\hline & Total sugars & 554.5 & $771.1 * *$ & 0.58 & $0.87^{*}$ \\
\hline & $\mathrm{K}^{+}$ & 984.7 & $873.4^{*}$ & 1.03 & 0.99 \\
\hline \multirow{9}{*}{$\begin{array}{l}\text { Mature } \\
\text { leaves }\end{array}$} & . & & & & \\
\hline & Sugars & & & & \\
\hline & Gluce & 40.23 & 56. & 0.04 & 0.06 \\
\hline & Sucrose & 63.24 & $22.00^{*}$ & 0.07 & $0.02^{* *}$ \\
\hline & Sorbose & 0.00 & 4.88 & 0.00 & 0.01 \\
\hline & Fructose & 46.40 & 46.73 & 0.05 & 0.05 \\
\hline & Sorbitol & 359.2 & $672.34 * *$ & 0.38 & $0.73^{* *}$ \\
\hline & Total sugars & 509.0 & $802.34^{* *}$ & 0.53 & $0.87^{* *}$ \\
\hline & $\mathrm{K}^{+}$ & 1081.3 & $919.53^{* *}$ & 1.13 & $0.99 *$ \\
\hline \multirow[t]{8}{*}{ Roots } & Sugars & & & & \\
\hline & Glucose & 67.96 & 79.12 & 0.04 & 0.06 \\
\hline & Sucrose & 26.24 & 25.91 & 0.02 & 0.02 \\
\hline & Sorbose & 0.00 & 0.00 & 0.00 & 0.00 \\
\hline & Fructose & 50.53 & 65.72 & 0.03 & $0.05^{*}$ \\
\hline & Sorbitol & 88.36 & $249.1^{* *}$ & 0.05 & $0.20^{* *}$ \\
\hline & Total sugars & 233.1 & $419.8^{* *}$ & 0.13 & $0.34^{* *}$ \\
\hline & $\mathrm{K}^{+}$ & 448.1 & $297.3^{* *}$ & 0.25 & 0.24 \\
\hline
\end{tabular}

*,**Significantly different from control at $P=0.05$ and 0.01 , respectively ( $t$ test, $\mathrm{n}=5$ ). weight basis can be misleading as solutes may be dissolved in smaller volumes of water in stress-acclimated tissues, resulting in lower $\Psi_{\pi, \text { sat }}$.

Stress-induced changes in potassium concentration contributed to a small decrease in $\Psi_{\pi \text {,sat }}$ in terminal leaves of 'Colt', but resulted in increases or no change in $\Psi_{\pi \text {,sat }}$ in all other tissues of both cultivars. The increases in total soluble carbohydrates contributed to decreases $\operatorname{in} \Psi_{\pi \text {,sat }}$ in all tissues of both cultivars, often by $>2$-fold.

Estimates of the contribution of solutes to the $\Psi_{\pi \text { sat }}$ of the expressed sap showed that the measured solutes (soluble carbohydrates and potassium) accounted for a large percentage (50\% to $83 \%$ ) of the measured $\Psi_{\pi \text {,sat }}$ (Table 2). Generally, the bulk of the stress-induced reduction in $\Psi_{\pi \text {,sat }}$ could be accounted for by increased levels of soluble carbohydrates, more specifically sorbitol.

\section{Discussion}

Terminal leaves of 'Colt' cherry were found to have higher $\Psi_{\pi \text {,sat }}$ than older leaves when well watered, similar to reports on apple (Lakso et al., 1984) and citrus (Syvertsen et al., 1981). Expanding leaves of 'Colt' demonstrated a significant capacity for osmotic adjustment, such that terminal leaves of water-stressed plants had $\Psi_{\pi \text {,sat }}$ similar to that of older stressed leaves. Other studies have found that sorbitol is synthesized primarily in older leaves in apple (Loescher et al., 1982) and apricot (Bieleski and Redgwell, 1985), suggesting that osmotic adjustment in expanding leaves resulted either from increased translocation of sorbitol to young leaves or from a decreased rate of sorbitol metabolism.

In 'Meteor', terminal leaves were similar to older leaves in $\Psi_{\pi, \text { sat }}$ and capacity for osmotic adjustment. This response is probably due to the determinate growth habit of 'Meteor' and the maturity of terminal leaves when sampled.

The higher osmotic potential of roots than of leaves, for both cultivars, is consistent with work done on other woody species,

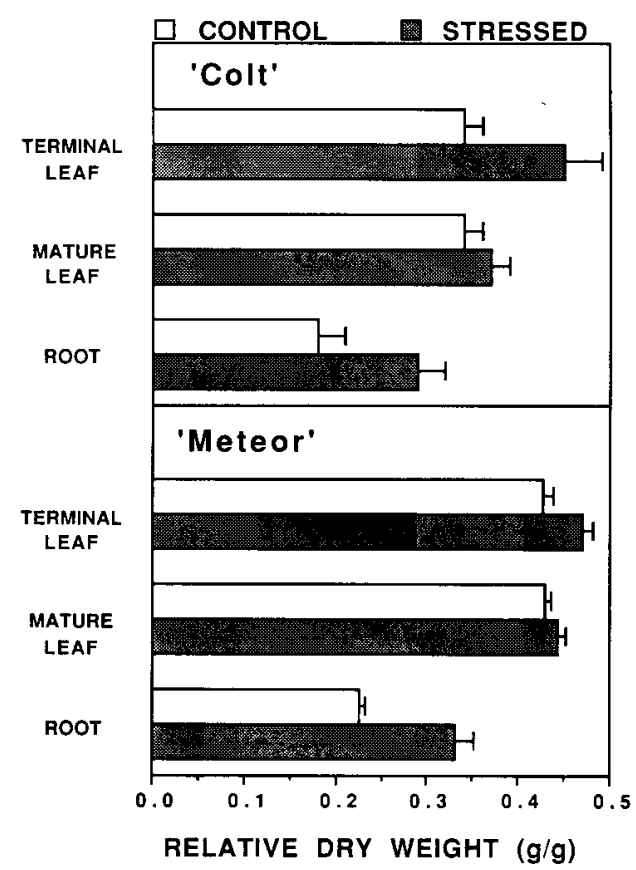

ig. 2. Relative dry weight of saturated tissue [dry wt/(saturated wt - dry wt)] for terminal leaves, mature leaves (16th node), and roots. Values are means \pm 2 SEM. 
Table 2. Contribution of measured solutes to $\Psi_{\pi, \text { sat }}$.

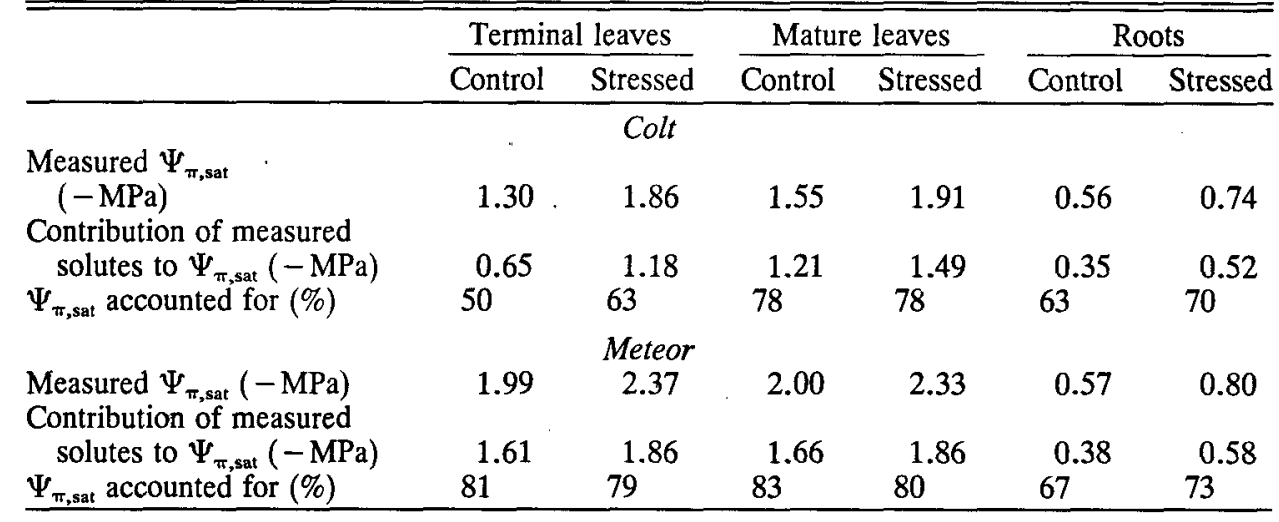

including Tsuga heterophylla (Kandiko et al., 1980), Pseudotsuga menziesii (Ritchie and Shula, 1984), Juglans nigra (Parker and Pallardy, 1985), and Quercus spp. (Parker and Pallardy, 1988). Although $\Psi_{\pi, \text { sat }}$ is typically higher in roots than leaves, the greater elasticity of root tissue can contribute to decreased water content and increased solute concentration as tissue water potential declines, often resulting in similar water potential at the turgor loss point for both leaves and roots (Parker and Pallardy, 1985, 1988; Ranney, 1989).

High solute concentrations can contribute to a greater capacity for turgor maintenance; however, high concentrations of electrolytes in the cytoplasm can be disruptive to organelles, enzymes, and membrane-bound processes (Wyn Jones et al., 1979). It has been proposed that polyols, such as sorbitol, may serve as more compatible solutes, being tolerated at high concentrations in the cytoplasm (Ahmad et al., 1979; Bieleski, 1982; Schobert, 1977).

Although the degree of osmotic adjustment was similar for leaves of both cultivars, 'Meteor' typically had a $\operatorname{lower} \Psi_{\pi, \text { sat }}$ than did 'Colt' for a given irrigation treatment. In a study of reciprocal graft combinations between 'Meteor' and 'Colt', plants with 'Meteor' scions maintained higher stomatal conductance and had higher mean net assimilation rates under water-stressed conditions than plants with 'Colt' scions, regardless of the rootstock (Ranney, 1987). The greater conductance and mean net assimilation rate of 'Meteor' scions may have been due to lower $\Psi_{\pi, \text { sat }}$ and greater capacity for turgor maintenance as found for 'Meteor' in this study. Furthermore, the difference in $\Psi_{\pi \text {, sat }}$ found between these two cultivars suggests the potential for further selection of Prunus cultivars, particularly scions, for low $\Psi_{\pi, \text { sat }}$ and possibly superior drought resistance.

\section{Literature Cited}

Ahmad, I., F. Larher, and G.R. Stewart. 1979. Sorbitol, a compatible osmotic solute in Plantago maritima. New Phytol. 82:671-678.

Bieleski, R.L. 1982. Sugar alcohols, p. 158-192. In: F.A. Loewus and W. Tanner (eds.). Plant carbohydrates I: intracellular carbohydrates: Springer Verlag, New York.

Bieleski, R.L. and R.J. Redgwell. 1985. Sorbitol versus sucrose as photosynthesis and translocation products in developing apricot leaves. Austral. J. Plant Physiol. 12:657-668.

Boersig, M,R. and F.B. Negm. 1985. Prevention of sucrose inversion during preparation of HPLC samples. HortScience 20:1054-1056.

Cochran, W.G. and G.M. Cox. 1957. Experimental designs. 2nd ed. Wiley, New York.

Cutler, J.M. and D.W. Rains. 1978. Effects of water stress and hardening on the internal water relations and osmotic constituents of cotton leaves. Physiol. Plantarum 42:261-268.
Ford, C.W. and J.R. Wilson. 1981. Changes in levels of solutes during osmotic adjustment to water stress in leaves of four tropical pasture species. Austral. J. Plant Physiol. 8:77-91.

Handa, S., R.A. Bressan, A.K. Handa, N.C. Carpita, and P.M. Hasegawa. 1983. Solutes contributing to osmotic adjustment in cultured plant cells adapted to water stress. Plant Physiol. 73:834-843.

Hinckley, T.M., R.O. Teskey, F. Duhme, and H. Richter. 1981. Temperate hardwood forests, p. 154-197. In: T.T. Kozlowski (ed.). Water deficits and plant growth IV: Woody plant communities. Academic, New York.

Jones, H.G., A.N. Lakso, and J.P. Syvertsen. 1985. Physiological control of water status in temperate and subtropical fruit trees. Hort. Rev. 7:301-344.

Kandiko, R.A., R. Timmis, and J. Worrall. 1980. Pressure-volume curves of shoots and roots of normal and drought conditioned western hemlock seedlings. Can. J. For. Res. 10:10-16.

Knipling, E.B. 1967. Effects of leaf aging on water deficit-water potential relationships of dogwood leaves growing in two environments. Physiol. Plant. 20:65-72.

Lakso, A.N. 1983. Morphological and physiological adaptations for maintaining photosynthesis under water stress in apple trees, p. 8593. In: R. Marcelle, H. Clijsters, and M. van Poucke (eds.). Effects of stress on photosynthesis. Nijhoff/Junk, The Hague.

Lakso, A.N., A.S. Geyer, and S.G. Carpenter. 1984. Seasonal osmotic relations in apple leaves of different ages. J. Amer. Soc. Hort. Sci. 109:544-547.

Loescher, W.H., G.C. Marlow, and R.A. Kennedy. 1982. Sorbitol metabolism and sink-source interconversions in developing apple leaves. Plant Physiol. 70:335-339.

Munns, R. and R. Weir. 1981. Contribution of sugars to osmotic adjustment in elongating and expanded zones of wheat leaves during moderate water deficits at two light levels. Austral. J. Plant Physiol. 8:93-105.

Munns, R., C.J. Brady, and E.W.R. Barlow. 1979. Solute accumulation in the apex and leaves of wheat during water stress. Austral. J. Plant Physiol. 6:379-389.

Nobel, P.S. 1983. Biophysical plant physiology and ecology. Freeman, New York.

Osonubi, O. and W.J. Davies. 1978. Solute accumulation in leaves and roots of woody plants subjected to water stress. Oecologia 32:323332.

Parker, W.C. and S.G. Pallardy. 1985. Genotypic variation in tissue water relations of leaves and roots of black walnut (Juglans nigra) seedlings. Physiol. Plant. 64:105-1 10.

Parker, W.C. and S.G. Pallardy. 1988. Leaf and root osmotic adjustment in drought-stressed Quercus alba, Q. macrocarpa, and $Q$. stellata seedlings. Can. J. For. Res. 18:1-5.

Ranney, T.G. 1987. The relative influence of roostock and scion on drought tolerance in cherries. MS Thesis, Cornell Univ., Ithaca, N.Y.

Ranney, T.G. 1989. Comparative physiology and drought tolerance in selected woody plants. PhD Diss., Cornell Univ., Ithaca, N.Y. 
Ritchie, G.A. and R.G. Shula. 1984. Seasonal changes of tissue-water relations in shoots and root systems of douglas-fir seedlings. For. Sci. 30:538-548.

Rem, C.R., R. Huw Tyson, and W.H. Loescher. 1988. Photosynthesis, carbohydrates, and water relations in sweet cherry (Prunus avium L.). Plant Physiol., Suppl. 86:89. (Abstr.)

Schobert, B. 1977. Is there an osmoregulatory mechanism in algae and higher plants? J. Theoretical Biol. 68:17-26.

Syvertsen, J.P., M.L. Smith Jr., and J.C. Allen. 1981. Growth rate and water relations of citrus leaf flushes. Ann. Bot. 47:97-105.

Turner, N.C. 1986. Adaptation to water deficits: a changing perspective. Austral. J. Plant Physiol. 13:175-190.

Turner, N.C., J.E. Begg, and M.L. Tonnet. 1978. Osmotic adjustment of sorghum and sunflower crops in response to water deficits and its influence on the water potential at which stomata close. Austral. J. Plant Physiol. 5:597-608.
Tyree, M.T. 1976. Physical parameters of the soil-plant-atmosphere system: breeding for drought resistance characteristics that might improve wood yield, p. 329-348. In: M.G.R. Cannell and F.T. Last (eds.). Tree physiology and yield improvement. Academic, New York.

Tyree, M.T. and P.G. Jarvis. 1982. Water in tissues and cells, p. 3577. In: O.L. Lange, P.S. Nobel, C.B. Osmond, and H. Ziegler (eds.). Physiological plant ecology II: water relations and carbon assimilation. Springer-Verlag, New York.

Tyree, M.T., Y.N.S. Cheung, M.E. MacGregor, and A.J.B. Talbot. 1978. The characteristics of seasonal and ontogenetic changes in the tissue-water relations of Acer, Populus, Tsuga, and Picea. Can. J. Bot. 56:635-647.

Wyn Jones, R.G., C.J. Brady, and J. Speirs. 1979. Ionic and osmotic relations in plant cells, p. 63-103. In: D.L. Laidman and R.G. Wyn Jones (eds.). Recent advances in the biochemistry of cereals. Academic, New York. 